\title{
PELATIHAN KREATIVITAS KEWIRAUSAHAAN PADA KELOMPOK UMKM DI KAMPUNG MINAPADI KELURAHAN NUSUKAN KECAMATAN BANJARSARI SURAKARTA
}

\author{
Endah Nawangsasi ${ }^{1)^{*}}$, Denny Mahendra ${ }^{2)}$, Yusuf Sutanto $^{3)}$ \\ STIE Adi Unggul Bhirawa Surakarta \\ *Email : Ajiraisp@gmail.com
}

\begin{abstract}
ABSTRAK
Kreativitas dalam pengelolaan usaha sangat diperlukan untuk memperoleh peluang pada situasi pandemik Covid-19 saat ini. Persaingan usaha di sektor mikro, kecil, dan menengah sudah tidak terbendung lagi. Sisi legalitas melalui format pembuatan Surat Ijin Usaha Perdagangan (SIUP) dan Surat Ijin Tempat Usaha adalah salah satu syarat bagi suatu pengusaha UMKM untuk menumbuhkan kepercayaan konsumen bagi produk atau jasa yang dikelolanya. Metode pengabdian masyarakat yang dipakai dalam program ini adalah pelatihan pembuatan SIUP dan SITU,serta membangun mental positif untuk menumbuhkan kreativitas dalam memanfaatkan peluang di situasi pandemik ini.Teknik pelatihan dengan melakukan sinergi mitra yang terdiri dari masyarakat di Kelurahan Nusukan (PKK), Bank Sampah Kelurahan Nusukan, Kader BKKBN, Tim Teknis Kreatif Kelurahan Nusukan.Tujuan akhir dari pengabdian masyarakat ini adalah menciptakan kesadaran mengenai aspek legalitas usaha serta memotivasi kreativitas dalam pengembangan kewrirausahaan sehingga produk dan jasa dapat dipasarkan dengan media online.Hasil pengabdian ternyztz membawa dampak pada meningkatnya pemahaman aspek legalitas usaha serta mental positif masyarakat dalam memannfaatkan peluang pada situasi pandemik ini dengan kreativitas produk melalui daur ulang sampah plastik.
\end{abstract}

Kata kunci: Kreativitas Wirausaha, Aspek LegalitasUsaha,Mental Positif,

\section{PENDAHULUAN}

Pengelolaan usaha dan strategi kewirausahaan sangat diperlukan dalam berwirausaha, karena tanpa pengetahuan tersebut seorang calon wirausaha atau enterpreneur bagaikan berjalan dalam kegelapan tanpa arah dan tujuan yang pasti oleh karena itu sangat penting seorang wirausaha merencanakan usaha apa yang mau dijalankan, sehingga akan mengetahui Isi, Visi, dan Peluang yang akan terjadi didepannya, serta dapat memahami kemampuan dan ketrampilan dalam mengelola usahanya.

Unsur - unsur yang harus ada dalam perencanaan usaha antara lain :Ringkasan Pelaksanaan Operasional Usaha, profil usaha, strategi usaha, produk dan jasa, strategi pemasaran, analisis pesaing, Ringkasan karyawan dan pemilik, rencana operasional, data finansial proposal, jadwal operasional. Bertolak dari hal tersebut diatas, minat bisnis dikalangan masyarakat yang ekonominya berpenghasian tinggi sudah merupakan hal biasa, karena mereka mudah mendapatkan uang atau modal, berbeda dengan masyarakat yang ekonominya menengah dan bawah, mereka sering mengalami kesulitan dalam memulai proses usaha. Akses mendapatkan modal juga terbentu pengetahuan yang biasa saja. Hal tersebut membuat masyarakat menjadi non-bankables dalam proses pengajuan kredit. Hal seperti ini juga dialami kelompok UKM dikampung Minapadi, Kelurahan Nusukan, Kecamatan Banjarsari, Surakarta.

Kelurahan Nusukan Surakarta mempunyai luas wilayah 508,80 ha dari seluruh Kecamatan Banjarsari yang memiliki luas wilayah 1.481,10 ha, dengan 13 Kelurahan, 169 RW, 849 RT, dan 40.245 KK dan jumlah penduduk 161.492 jiwa. Kelurahan Nusukan memiliki 27 RW, 193 RT, dan 9.774 KK dan jumlah penduduk 35.805 jiwa (B.PS kota Surakarta 2010). Keberadaan UMKM mulai tumbuh di wilayah tersebut hal itu dapat dilihat perputaran ekonomi makin berkembang. Melalui Tim Pengabdian Kepada Masyarakat yang dilakukan oleh STIE-AUB dengan Topik Pelatihan Kreativitas Kewirausahaan pada kelompok UMK Kampung Minapadi, Kelurahan Nusukan, Kecamatan Banjarsari, Surakarta. 
Melalui pengamatan Tim Pengabdian STIE AUB, ada beberapa kelemahan sumberdaya manusia dalam menjalankan usahany. Adapun yang dimaksud adalah mereka Kelompok UMKM yang sudah memiliki kreativitas usaha dan sudah memasarkan produk atau jasa secara manual maupun online, ternyata belum memiliki Surat ijin Usaha perdagangan (SIUP) Surat Ijin Tempat Usaha (SITU). Berdasar situasi permasalahan tersebut Tim Pengabdian STIE-AUB Nusukan, tergerak untuk membantu kelompok UMK dalam berwirausaha, khususnya dalam membuat Surat Ijin Usaha Perdagangan (SIUP) dan Surat Ijin Tempat Usaha(SITU). Hal tersebut bertujuan agar UMKM dapat menjalankan usahanya dengan lancar dan tenang karena sudah mentaati aturan-aturan dan persyaratan dalam dunia usaha. Berdasarkan uraian yang disampaikan pada analisa situasi diatas terdapat beberapa identifikasi permasalahan yaitu sebagai yaitu: Kurangnya pengetahuan sumber daya manusia pelaku UMKM di Minapadi Nusukan dibidang perizinan dagang atau bisnis sehingga berdampak dalam pengelolaan usaha. Megacu permasalahan tersebut diatas perlu perumusan masalah dalam program pengabdian kepada masyarakat yaitu :

1. Bagaimana para pelaku usaha Mikro kecil dan menengah di Kampung Minapadi dapat meningkatkan pengetahuan tentang pembuatan Surat Ijin Usaha Perdagangan (SIUP) dan Surat Ijin Tempat Usaha (SITU).

2. Bagaimana para pelaku usaha Mikro kecil dan menengah di kampung Minapadi dapat terampil membuat Surat Ijin Usaha Perdagangan (SIUP) dan Surat Ijin Tempat Usaha (SITU)

3. Bagaimana meningkatkan mental positif Kreativitas Usaha seiring dengan kondisi suasana Usaha yang terkena dampak Covid-19?

Bertolak dari hal tersebut diatas, tujuan kegiatan Pengabdian Kepada Masyarakat adalah sebagai berikut:

1. Memberikan motivasi dan pengalaman kepada pelaku UMKM dalam membuat surat-surat izin sebelum usaha dagang dimulai.

2. Membantu pelaku UMKM dalam pembuatan surat-surat izin usaha secara benar sesuai persyaratan hukum, dalam hal ini menyangkut perencanaan dan operasional usaha.

3. Mengetahui apakah ada perubahan pola pelaku usaha dalam proses berkaitan pengelolaan usaha setelah diadakan pelatihan melalui pengabdian kepada masyarakat.

\section{METODE PENGABDIAN}

Melalui permasalahan yang muncul disusun berbagai alternatif untuk memecahkan masalah, selanjutnya dari berbagai alternatif, dipilih alternatif yang paling mungkin dilaksanakan. Berdasarkan kerangka berpikir tersebut, maka metode dalam kegiatan ini adalah sebagai berikut :

\section{Permasalahan}

1. Kesenjangan wawasan praktis kewirausahaan.

2. Kesenjangan Ketrampilan pembuatan surat izin usaha.

3. Dampak Covid 19 terhadap mental berwirausaha

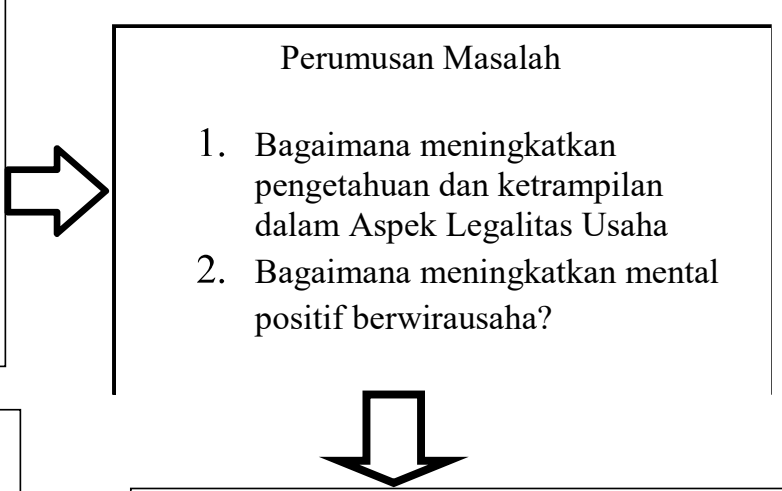

1. Melengkapi teori yang kewirausahaan untuk menambah wawasan pembuatan surat izin usaha.

2. Membawa pengalaman praktek peserta tentang pembuatan surat izin usaha.

3. Praktik Pembuatan Hand Sanitizer

Alternatif Pemecahan Masalah

1. Pelatihan membuat surat izin usaha (SIUP dan SITU)

2. Motivasi Usaha dengan mencari peluang usaha paska pandemik 


\section{HASIL PEMBAHASAN}

Pelaksanaan kegiatan Pengabdian Masyarakat dengan judul “ Pelatihan Kreativitas Kewirausahaan di Kampung Minapadi, Kelurahan Nusukan, Kecamatan Banjarsari, Surakarta “, telah selesai dilakukan. Kegiatan pengabdian ini telah dilaksanakan pada 11 Juli 2020, yang bertempat di Kampung Minapadi, Kelurahan Nusukan, Kecamatan Banjarsari. Kegiatan pengabdian ini telah diisi dengan materi mengenai bagaimana syarat-syarat sebelum seorang pengusaha membuat usaha yaitu dengan menyiapkan surat-surat izin usaha. Kegiatan pengabdian pada masyarakat diikuti jumlah peserta yang hadir 21 orang, berisi dari penduduk lokal sekitar lokasi kampung Minapadi. Para peserta sangat antusias untuk mengikuti kegiatan ini, dibuktikan dengan kedatangan mereka yang mengikuti acara kegiatan sampai selesai.. Sebelum mulai penyampaian materi, terlebih dahulu memberikan pertanyaan sebagai pre-test. Pertanyaan pre-test diberikan untuk mengetahui sejauh mana pengetahuan dan pemahaman peserta dalam dunia bisnis. Pertanyaan yang diberikan meliputi apakah peserta sudah memiliki bisnis, bagaimana cara memulai bisnis, bagaimana operasional bisnis dan bagaimana cara memasarkan usaha. Materi pertama adalah tentang pembuatan surat-surat izin usaha yang disampaikan oleh Dra. Endah Nawangsasi, M.M. Aspek Legalitas menjadi bahan dalam memotivasi masyarakat dalam berwirausaha karena menjadi salah satu syarat dalam proses pengajuan kredit. Selain itu juga dapat menumbuhkan kepercayaan yang baik bagi pelanggan potensial dan pelanggan utama. Keberadaan SIUP,TDP,SITU,HO akan membawa umkm menjadi naik kelas. Hal tesebut menuntut para pelaku UMKM, khususnya di wilayah Minapadi Nusukan meningkatkan pengetahuan dan ketrampilannya. Aspek legalitas juga mampu menumbuhan jaringan bagi pelaku UKM karena diskusi berkaitan dengan hal tersebut dapat menambah semangat untuk proses naik kelas, yang ditandai dengan proses UMKM menjadi bank-able. Kedekatan terhadap akses bank akan membuat UMKM juga menuntut untuk cermat dalam menganalisa laporan keuangan. Jadi dalam hal ini pengetahuan dan ketrampilan terhadap aspek legalitas usaha membawa multiplier efek dalam pengembangan usaha.

Materi kedua disampaikan oleh Denny Mahendra, SE, M.M, tentang bagaimana memanfaatkan peluang di era pandemik ini dengan kreativitas membuat hand sanitizer secara alami. Hal tersebut diawalai dengan melakukan motivasi dengan membangun mental wirausaha bagi pelaku UMKM. Kondisi pandemik tentunya membuat suasana usaha menjadi kurang kondusif. Misalnya berkaitan dengan fluktuasi harga, upaya akses bahan baku yang terkendala, daya beli masyarakat yang turun dan lain-lain. Disini diperlukan upaya untuk meyakinkan pembeli agar lebih safety, dengan melakukan kampanye penggunaan protokol kesehatan yang sesuai dengan standar. Peluang usaha juga harus bisa dimanfaatkan secara kreatif, misalnya dengan membuat produk-produk alat pelindung diri dari virus covid, yaitu Hand Sanitizer dan Disinfektan. Harga jual produk tersebut di toko atau supermarket tentunya lebih mahal dibandingkan dengan ketika kita bisa membuat produk tersebut secara alami dan mandiri. Melalui pengabdian ini disampaikan proses pembuatan produk Disinfektan sebagai peluang untuk berwirausaha paska pandemik ini.

Materi ketiga sebagai Penutup dibawakan Yusuf Sutanto berkaitan dengan pemanfaatan Tokopedia sebagai chanel Pemasaran Digital untuk pemula. Tokopedia merupaka E-Commerce yang menjalin kemitraan dengan pelaku usaha. Siapapun dapat menjual produk dan jasanya melalui chanel pemasaran digital ini.Ditinjau secara pencitraan merk tentunya banyak orang yang sudah kenal dengan Tokopedia, namun belum mendalami konten yang ada di dalamnya. Pengenalan konten Tokopedia dalam proses pemasaran usaha membawa para pelaku usaha untuk dapat meningkatkan kompetensinya dalam IPTEK untuk mendukung usaha.

\section{KESIMPULAN}

Beberapa kesimpulan dari hasil kegiatan pengelolaan kepada masyarakat, antara lain : 
a. Pemahaman peserta tentang Aspek Legalitas Kewirausahaan tentang pembuatan surat-surat sebelum memiliki usaha yaitu surat izin usaha diantaranya surat izin gangguan (HO) dan surat izin tempat usaha (SITU) akan membawa UMKM menjadi naik kelas.

b. Pemahaman peserta tentang pentingnya surat-surat izin usaha sebelum mendirikan usaha membawa UMKM lebih dekat terhadap akses permodalan karena lebih bank-able

c. Pemahaman peserta tentang pemasaran Digital yang efektif dapat meningkatkan pembeli potensial dan menjalin relasi yang lebih dekat dengan pelanggannya

d. Peluang usaha di masa Pandemik Covid-19 perlu dibangun melalui mental positif dalam kreativitas usaha.

\section{SARAN}

a. Peningkatan pemahaman Aspek Legalitas dalam Pengelolaan usaha perlu diimbangi dengan pemberdayaan TIM Kreatif dalam kegiatan kemasyarakatan di Minapadi Nusukan

b. Pembangunan mental positif masyarakat dalam memanfaatkan peluang pada masa pandemik covid-19, harus berkelanjutan untuk pengembangan usaha.

Pada akhirnya TIM Pengabdian masyarakat STIE AUB Surakarta mengucapkan terimakasih kepada pihak Pemerintah Kalurahan Nusukan Banjarsari melalui beberapa kelembagaan kreatifnya seperti Bank Sampah, Kader BKKBN, Tim Penggerak PKK sehingga publikasi ini dapat diselesaikan. Harapannya ke depan semangat masyarakat untuk berkreativitas akan tetap bertumbuh dalam menciptakan peluang di era covid-19 ini.

\section{DAFTAR PUSTAKA}

Azizah, S. N. 2013. Pengaruh Motivasi Usaha dan Kemampuan Usaha dalam Meningkatkan Keberhasilan Usaha Pada Usaha Mikro Pedagang Sate di Desa Candiwulan Kecamatan Adimulyo Kebumen. Jurnal Fokus Bisnis, 12(01)

Farida, E., \& Widayanti, R. 2015. Analisis Pengaruh Motivasi, Kemampuan Kerja dan Jiwa Wirausaha terhadap Keberhasilan Usaha pada Sentra Kripik Tempe Sanan Malang. Jurnal Akuntansi, Bisnis, dan Manajemen, 22(01)

Nordiana, E. 2014. Peran Jejaring Sosial Sebagai Media Peningkat Minat Berwirausaha Mahasiswa Untuk Berbisnis Online (Studi Pada Mahasiswa Jurusan Ilmu Ekonomi Universitas Brawijaya)

Nugraha, A., \& Wahyuhastuti, N. 2017. Start Up Digital Business: Sebagai Solusi Penggerak Wirausaha Muda. Jurnal Nusamba, 2(01)

Nursito, S., \& Nugroho. 2013. Analisis Pengaruh Interaksi Pengetahuan Kewirausahaan dan Efikasi Diri Terhadap Intensi Kewirausahaan. Kiat BISNIS, 05(03)

Pradiani, T. 2017. Pengaruh Sistem Pemasaran Digital Marketing Terhadap Peningkatan Volume Penjualan Hasil Industri Rumahan. JIBEKA, 11(02) 
Purnama, C., \& Suyanto. 2010. Motivasi dan Kemampuan Usaha dalam Meningkatkan Keberhasilan Usaha Industri Kecil (Studi Pada Industri Kecil Sepatu di Jawa Timur). Jurnal Manajemen dan Kewirausahaan, 12(02)

Srirejeki, K. 2016. Analysis Of The Use Of Social Media To Empower Small Micro Medium Enterprise (SMEs). Jurnal Masyarakat Telematika dan Informasi, 7(01)

Susrini. 2017. Peran Media Sosial di Era Modern. UI Press

Widyastuti, D. A., \& Nuswantoro, R. 2016. Literasi Digital Pada Perempuan Pelaku Usaha Produktif Di Daerah Istimewa Yogyakarta. Jurnal ASPIKOM, 3(01)

Yusriadi. 2018. Manajemen Perubahan dalam Reformasi Birokrasi menuju Information Technology (IT). Jurnal Mitra Manajemen. 